\title{
'UF-404' - a New University of Florida Caladium Variety for Use in the Container and the Landscape ${ }^{1}$
}

\section{Zhanao Deng ${ }^{2}$}

'UF-404' is a red, lance-leaved caladium variety with a unique coloration pattern (bright red with colorful blotches). This variety produces a good amount of tubers, and it sprouts early. As a result, it can quickly develop many large leaves. De-eyeing is not required for producing quality pot plants in containers although de-eying can increase leaf number and results in shorter plants with smaller leaves. 'UF-404' has excellent resistance to leaf sunburn and chilling injury. These characteristics make this variety well suited for container forcing and landscape use.

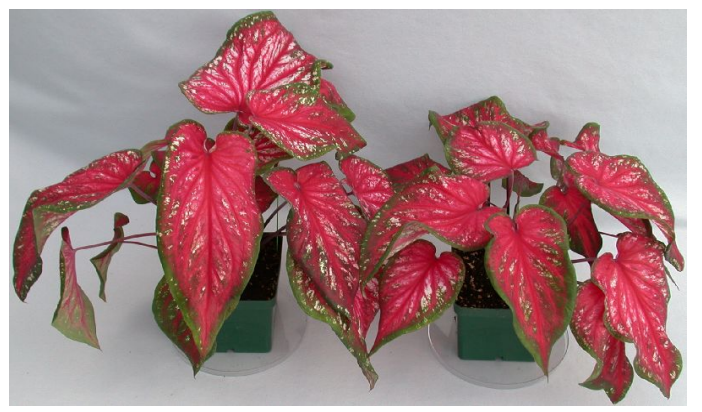

Figure 1. 'UF-404' plants forced in containers. Plants from one intact (left) and one de-eyed (right) No. 1 tuber (1 1/2 $21 / 2$ inches in diameter), planted in $41 / 2$-inch square pots and photographed eight weeks after planting.

Credits: Richard O. Kelly

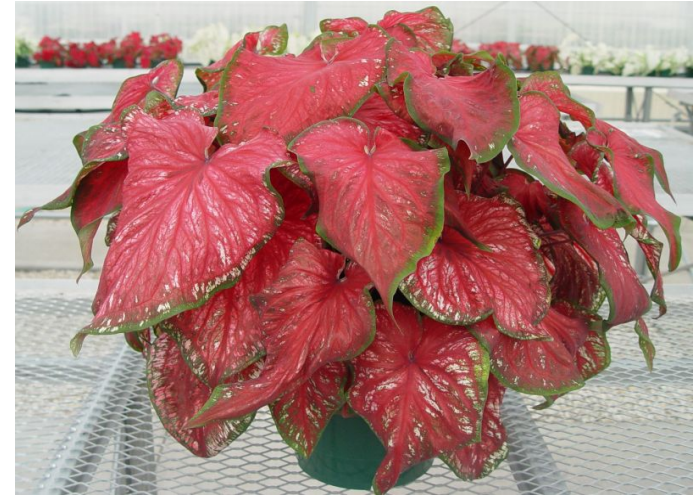

Figure 2. Plants from three intact Jumbo (2 1/2 - $31 / 2$ inches in diameter) tubers, planted in a 10 -inch pot and photographed 10 weeks after planting. Credits: Zhanao Deng

\section{Origin}

'UF-404' was developed from a cross between two commercial varieties, 'Florida Blizzard' and 'Florida Red Ruffles'. 'Florida Blizzard' was selected from a cross between 'Aaron' and 'White Christmas' and released for commercial production in 2001 (Harbaugh et al., 2002). 'Florida Red Ruffles' resulted from a cross between 'Red Frill' and a progeny of 'Red Frill' x 'Candidum Junior' (Wilfret, 1991). The ancestry of 'Aaron', 'Candidum Junior', 'Red Frill', and 'White Christmas' is unknown.

1. This document is ENH1106, one of a series of the Environmental Horticulture Department, Florida Cooperative Extension Service, Institute of Food and Agricultural Sciences, University of Florida. Original publication date, November 2008. Visit the EDIS Web site at http://edis.ifas.ufl.edu.

2. Zhanao Deng, assistant professor, Environmental Horticulture Department, Gulf Coast Research and Education Center -- Wimauma, FL, Institute of Food and Agricultural Sciences, University of Florida.

The Institute of Food and Agricultural Sciences (IFAS) is an Equal Opportunity Institution authorized to provide research, educational information and other services only to individuals and institutions that function with non-discrimination with respect to race, creed, color, religion, age, disability, sex, sexual orientation, marital status, national origin, political opinions or affiliations. U.S. Department of Agriculture, Cooperative Extension Service, University of Florida, IFAS, Florida A. \& M. University Cooperative Extension Program, and Boards of County Commissioners Cooperating. Larry Arrington, Dean 


\section{Description}

Leaves of 'UF-404' are lanceolate; leaf margins are dark green, but central and main veins are red to purple. Interveinal areas are red/purple near the leaf center to yellow-green or orange toward the margins and have irregular blotches (Figure 1). Plants grown for four months in full sun in ground beds have an average height of 11 inches. The largest leaves on plants can be up to 10 inches long and 7 inches wide. Jumbo-sized tubers (2 1/2 - $31 / 2$ inches in diameter) are multi-branched, and each tuber bears four to seven dominant buds.

\section{Tuber Production}

'UF-404' was evaluated for tuber production at the Gulf Coast Research and Education Center in Wimauma, Fla., in 2006 and 2007. 'Red Frill' and 'Florida Red Ruffles' (the two major red, lance-leaved varieties), as well as 'Florida Sweetheart' (the most popular lance-leaved varieties in all colors), were included as controls.

The soil was fine sand, containing approximately 1 percent organic matter and having a $\mathrm{pH}$ of 6.2. In 2006, raised ground beds ( 3 feet wide and 8 inches high) were fumigated with a mixture of methyl bromide and chloropicrin at the rate of 175 pounds per acre and covered with white-on-black plastic mulch.

Caladium seed tuber pieces were planted in the beds with 6-inch spacing between rows and within rows. A constant water table was maintained below the beds using the seep irrigation system. Osmocote 18-6-12 controlled-release fertilizer (eight to nine months) was applied at the rate of 300 pounds of nitrogen per acre when plants began to emerge from the ground.

In 2007, the beds (28 inches wide and 8 inches high) were fumigated using the same fumigant mixture. Caladium seed tuber pieces were planted with 10-inch between-row spacing and 6-inch in-row spacing. A drip irrigation system was used to deliver water and soluble fertilizer (6-2-8, approximately 1.7 pounds of nitrogen per acre per day). Thirty seed tuber pieces were planted in each plot in April 2006 and April 2007, and new tubers were harvested in December 2006 and January 2008, respectively.

Tubers were graded by their maximum diameter: No. 2 (1 - 1 1/2 inches), No. 1 (1 1/2 - $21 / 2$ inches), Jumbo (2 1/2 - 3 1/2 inches), Mammoth (3 1/2 - 4 1/2 inches), and Super Mammoth (>4 1/2 inches). A production index was calculated for each plot as follows: number of No. 2 tubers x $1+$ number of No. 1 tubers $x 2+$ number of Jumbo tubers $x 4+$ number of Mammoth tubers x $6+$ number of Super Mammoth tubers x 8 .

In 2006, 'UF-404' produced similar numbers of marketable tubers (44 - 52) as 'Florida Red Ruffles' and 'Florida Sweetheart'. However, 'UF-404' had the greatest tuber weight and the highest production index, with its tuber weight 95 percent and 68 percent higher than 'Florida Red Ruffles' and 'Florida Sweetheart'. Additionally, the production index for 'UF-404' was 56 percent and 39 percent higher than 'Florida Red Ruffles' and 'Florida Sweetheart', respectively (Table 1). 'UF-404' was superior to 'Red Frill' in tuber weight (3.9-fold), production index (2.3-fold) and marketable number of tubers (1.3-fold).

In 2007, 'UF-404' was similar to 'Florida Red Ruffles' and 'Florida Sweetheart' in tuber weight, production index, and marketable tubers, but superior to 'Red Frill' in all these assessments.

In tuber grade distribution, 'UF-404' was similar to 'Florida Red Ruffles' and 'Florida Sweetheart'. These three clutivars each produced a majority (60 percent or more) of tubers in the categories of No. 1, Jumbo, or Mammoth. Additionally, 'UF-404' produced larger tubers than 'Red Frill', which had more than 90 percent of tubers in the No. 1 and No. 2 categories. 


\section{Container Forcing}

The suitability of 'UF-404' for container forcing was evaluated by forcing tubers in 4 1/2-inch plastic pots. On March 26, 2007, No. 1 tubers were planted -either intact or de-eyed -- in a peat/vermiculite mix. The tubers were forced in a greenhouse with 45 percent light exclusion in Wimauma, Fla. Daily temperatures ranged from 60 - 84 degrees $\mathrm{F}$ in the greenhouse during the experiment.

'UF-404' produced excellent pot plants, regardless of tuber treatments (intact or de-eyed) (Table 2). When tubers were planted intact, 'UF-404' sprouted 30 days after planting, which was similar to the sprouting time of 'Red Frill' (32 days). However, 'UF-404' sprouted 9 - 13 days earlier than 'Florida Red Ruffles' and 'Florida Sweetheart'. When tubers were de-eyed, there was no significant difference in sprouting time between 'UF-404' and 'Florida Red Ruffles' and 'Florida Sweetheart'. 'UF-404' sprouted six days later than 'Red Frill' when tubers were de-eyed.

Intact or de-eyed plants of 'UF-404', 'Florida Red Ruffles', and 'Red Frill' were similar in height. 'UF-404' produced similar numbers of leaves as the control plants, but had larger leaves (1 - 4 inches longer and 1 - 3 inches wider than 'Florida Sweetheart' and 'Red Frill'). 'UF-404' and 'Florida Red Ruffles' were not significantly different in leaf width at the eighth week after planting. With multiple, bright colored leaves, containerized 'UF-404' plants received the highest (4.5 - 4.9) quality ratings when compared to the three commercial varieties (3.0 4.3).

\section{Landscape Performance}

Landscape performance of 'UF-404' under full-sun conditions was evaluated in 2006 and 2007 on the same plots used for evaluating tuber production. Plants were evaluated three times (July, August, and September) in each growing season, on a scale of $1-5$, with 1 being very poor (few leaves and lack of vigor), and 5 being excellent (full plants, numerous leaves, and bright color display). Leaf sunburn tolerance was also evaluated three times in each growing season on a scale of 1 - 5, with 1 being very susceptible to sunburn (leaves having numerous sun-damaged areas or holes) and 5 being resistant to sunburn (no visible sun-damaged areas).

All varieties tested produced a similarly high number of leaves typical of lance-leaved plants (Table 3). 'UF-404' plants were taller (2 - 5 inches taller) and developed larger leaves (1 - 4 inches longer and up to 3 inches wider) than those of 'Florida Red Ruffles', 'Florida Sweetheart', and 'Red Frill'.

With multiple large leaves, 'UF-404' formed full plants with excellent color display, resulting in higher performance ratings than the controls in most of the comparisons. In sunburn-tolerance ratings, 'UF-404' was similar to 'Florida Red Ruffles' and 'Florida Sweetheart' (4.0 - 4.4 through the growing season) and was better than 'Red Frill' in August and September.

\section{Chilling Resistance}

Mature leaves of 'UF-40' were detached from potted plants and exposed to 45 degree $F$ for three days in a growth chamber. The chilled leaves were then held at ambient temperatures for 10-11 days and examined for signs of chilling injury (chlorotic and necrotic areas). Four chilling tests were conducted in June to August 2007. 'Florida Red Ruffles' and 'Candidum' were used as the chilling-resistant and chilling-susceptible controls, respectively. 'UF-404' had less areas injured from the chilling treatment than both 'Candidum' and 'Florida Red Ruffles', indicating that 'UF-404' has better chilling resistance than those varieties (Table 4).

\section{Availability}

The caladium variety 'UF-404' will be sold and marketed under the trade name Dr. Brent. A plant patent application will be submitted to the U.S. Patent and Trademark Office. Plant patent rights will be assigned to the University of Florida, Board of Trustees. Propagation and distribution will be licensed by the Florida Foundation Seed Producers, Inc., P.O. Box 110200, Gainesville, FL 32611. Information on tuber availability and propagation agreements can be obtained from the Florida Foundation Seed Producers, Inc. 


\section{References Cited}

Deng, Z., B.K. Harbaugh, and N.A. Peres. 2008.

'UF-404' - dwarf, red caladium for container-forcing

and sunny landscapes. HortScience 43:1907 - 1910.

Harbaugh, B.K., B.D. Miranda, and G.J. Wilfret.

2002. Florida Blizzard - A white, fancy-leaved

caladium for large pots or shady landscapes.

HortScience 37:844-866.

Wilfret, G.J. 1991. 'Florida Red Ruffles' and

'Florida Irish Lace': Two new lance-leaf caladium

varieties. HortScience 31:564 (abstract).

Table 1. Tuber weight, production index, marketable tubers, and tuber grade distribution of 'UF-404' and three commercial caladium varieties when they were grown in replicated field trials (2006 and 2007). Values presented are means of three replications with 30 tuber pieces planted in each field plot (13.5 square feet).

\begin{tabular}{|c|c|c|c|c|c|c|c|c|}
\hline \multirow[b]{2}{*}{ Caladium varieties } & \multicolumn{3}{|c|}{ Tubers } & \multicolumn{5}{|c|}{ Tuber distribution (\%) } \\
\hline & $\begin{array}{l}\text { Weight } \\
\text { (LB) }\end{array}$ & $\begin{array}{c}\text { Production } \\
\text { index }\end{array}$ & $\begin{array}{c}\text { Marketable } \\
\text { (number) }\end{array}$ & $\begin{array}{c}\text { Super } \\
\text { Mammoth }\end{array}$ & Mammoth & Jumbo & $\begin{array}{c}\text { No. } \\
1\end{array}$ & $\begin{array}{c}\text { No. } \\
2\end{array}$ \\
\hline UF-404 & 104 & 155 & 52 & \multicolumn{5}{|c|}{ Year 2005 ---------------------------------------------------------- } \\
\hline Red Frill & 2.6 & 68 & 39 & 0 & 0 & 1 & 67 & 32 \\
\hline Florida Red Ruffles & 5.3 & 99 & 44 & 0 & 7 & 21 & 30 & 43 \\
\hline Florida Sweetheart & 6.2 & 111 & 50 & 1 & 3 & 20 & 49 & 27 \\
\hline UF-404 & 6.2 & 105 & 37 & 0 & 3 & 21 & 51 & 25 \\
\hline Red Frill & 4.2 & 66 & 39 & 0 & 0 & 8 & 45 & 47 \\
\hline Florida Red Ruffles & 6.0 & 84 & 42 & 0 & 1 & 20 & 41 & 38 \\
\hline Florida Sweetheart & 7.3 & 84 & 46 & 0 & 3 & 29 & 31 & 38 \\
\hline \multicolumn{9}{|c|}{$\begin{array}{l}\text { *The production index is an indicator of the economic value of the tubers harvested and is calculated as follows: } \mathrm{N} \text { (No. } 2) \\
+2 \mathrm{~N}(\text { No. } 1)+4 \mathrm{~N} \text { (Jumbo) }+6 \mathrm{~N} \text { (Mammoth) }+8 \mathrm{~N} \text { (Super Mammoth), where } \mathrm{N}=\text { number of tubers in each grade. } \\
\text { Tubers are graded by maximum diameter: No. } 2(1-11 / 2 \text { inches); No. } 1(11 / 2-21 / 2 \text { inches); Jumbo }(21 / 2-31 / 2 \text { inches); } \\
\text { Mammoth (3 } 1 / 2-41 / 2 \text { inches); and Super Mammoth (>4 } 1 / 2 \text { inches). }\end{array}$} \\
\hline
\end{tabular}




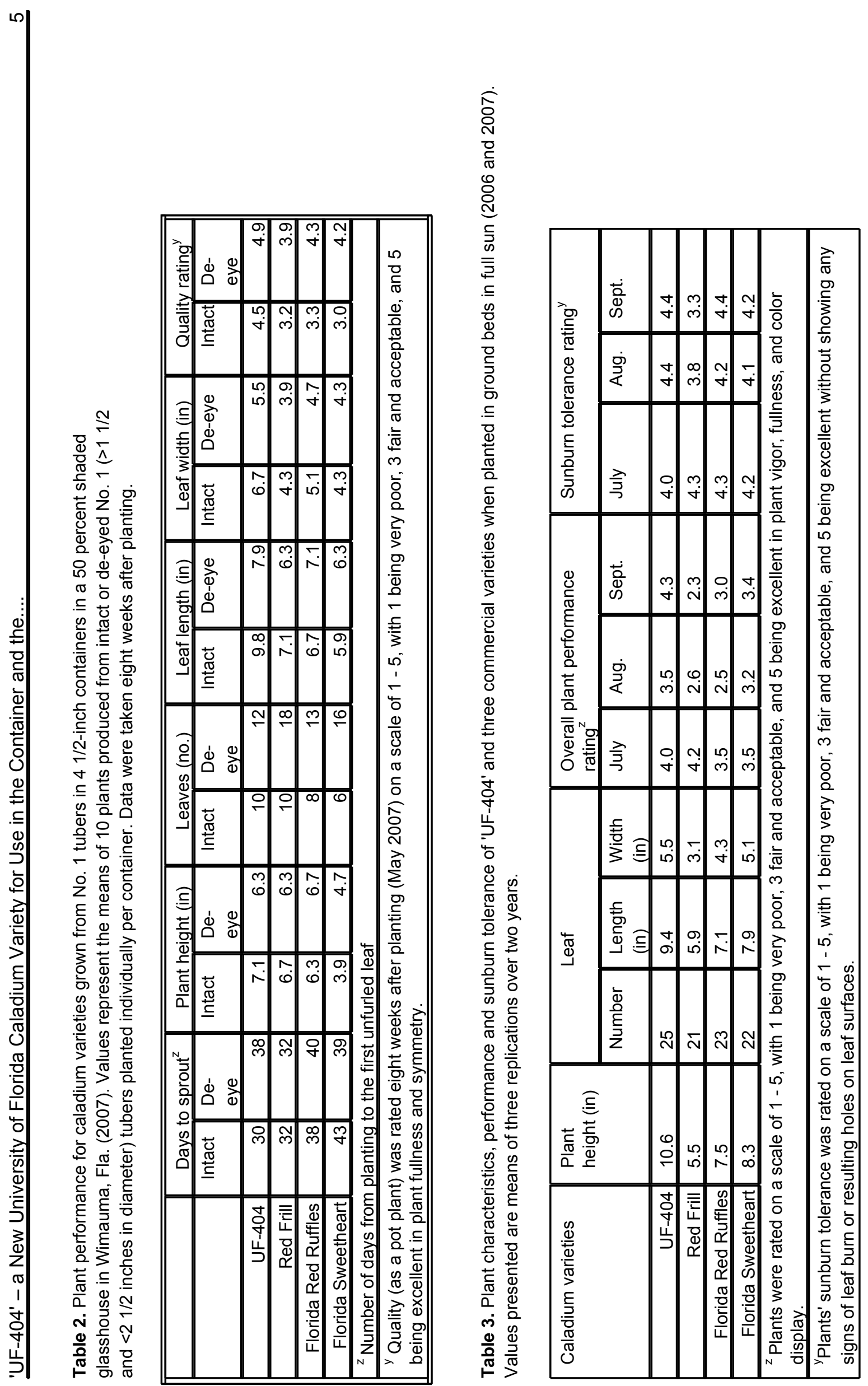


Table 4. Sensitivity of 'UF-404' and two commercial varieties to chilling injury caused by exposing to 45 degree $F$ for three days.

\begin{tabular}{|c|c|c|}
\hline Caladium varieties & Leaf area injured $(\%)^{z}$ & Leaf injury score $^{y}$ \\
\hline UF-404 & 43 & 7.4 \\
\hline Candidum & 90 & 9.8 \\
\hline Florida Red Ruffles & 63 & 8.5 \\
\hline \multicolumn{3}{|c|}{$\begin{array}{l}\text { z Percentage of leaf area injured was assessed 10-11 days after } \\
\text { chilling. }\end{array}$} \\
\hline \multicolumn{3}{|c|}{$\begin{array}{l}{ }^{y} \text { Scores were made on a scale of } 1-10: 1=\text { no injury, bright and } \\
\text { healthy as the control; } 2=\text { some discoloration or yellowing; } 3=1 \% \text { to } \\
2 \% ; 4=3 \% \text { to } 5 \% ; 5=6 \% \text { to } 10 \% ; 6=11 \% \text { to } 20 \% ; 7=21 \% \text { to } 35 \% \text {; } \\
8=36 \% \text { to } 55 \% ; 9=56 \% \text { to } 75 \% ; \text { and } 10=76 \% \text { to } 100 \% \text { of total leaf } \\
\text { area injured. }\end{array}$} \\
\hline
\end{tabular}

